\title{
Politics on the road to the U.S. monetary union
}

\author{
Peter L. Rousseau ${ }^{\mathrm{a}}$
}

December 19, 2012

\begin{abstract}
Is it possible to have a successful monetary union without a political one? It would seem that the early United States is a leading example from history of political union as a precondition for monetary stability. But this view is misleadingly simple. I review the historical record and reveal signs that the United States did not achieve a stable monetary union, if measured by a uniform currency and adequate safeguards against systemic risk, until well after the Civil War and probably not until the founding of the Federal Reserve. Political change and shifting policy positions end up as key factors in shaping the monetary union that did ultimately emerge.
\end{abstract}

JEL Codes: N11, N21, E42, E44

Keywords: colonial currency; Bank of the United States; Jacksonian monetary policy; free banking; National Banking System; Federal Reserve System.

${ }^{a}$ Professor of Economics, Vanderbilt University, Box 1819 Station B, Nashville TN 37235 USA. E-mail: Peter.L.Rousseau@Vanderbilt.Edu. 


\section{Introduction}

A recurring theme in discussions of challenges facing the Euro zone is the feasibility of a successful monetary union in a region that lacks a full political union. The early United States often arises in this context as a textbook example of a political union, forged by the Federal Constitution ratified in 1789, paving the way for future monetary stability (Rousseau and Sylla 2005; Rousseau 2011; Sargent 2012). This view contains strong elements of truth, but is misleadingly simple as a policy prescription. Indeed, the U.S. historical record indicates that politics interacted with the monetary and financial systems in an organic manner and that a stable monetary union, if defined as a system with a uniform currency and adequate safeguards against systemic risk, eluded the nation until well after the Civil War and probably not until the founding of the Federal Reserve. Moreover, monetary stability in the United States arose from the dual advantages of a de-centralized system of banks under a firm central authority, a notion somewhat removed from the Federalist vision of 1789.

When viewed in this light, the early United States was not much more of a "political union" in 1790 than today's European Union, though it did enjoy the advantages of a common culture and language early on. If history offers a roadmap for the future, it is likely that monetary stability in the EU will also arise through a similar sequence of informed trial and error across political and monetary actors, though knowledge of the past may accelerate the time frame this time around.

This is not to say that the Federal Constitution was unimportant. The lack of even a rudimentary political union among the thirteen colonies prior to their independence allowed, for example, individual colonies in New England to undermine a loose regional currency zone, and the weak political union that emerged with the Continental Congress during the Revolution 
(1776-1781) and then under the Articles of Confederation (1781-1789) aggravated the problems of monetary control. Moving to a single unit of account in the dollar, privatizing the money creation process, and ceding some fiscal authority to the Federal government after 1789 represented a leap towards having a well-functioning monetary union, but the process by no means ended there. Rather, political struggles caused the balance of power to shift between centralist and decentralist influences in the government and produced a patchwork of institutions and monetary practices that ended up being codified in the compromise that was the Federal Reserve Act of 1913.

The Federalist vision of a central bank was far from universally held in the 1790s. The anti-Federalist opposition attempted to stop the formation of a central bank - the First Bank of the United States - on constitutional grounds, and worried that excessive central control over monetary affairs through a quasi-private bank would sacrifice general prosperity in favor of "moneyed interests." They lost the first round in the conflict and the Bank was formed, but turned the tables two decades later when an Act to renew the Bank's initial 20-year charter failed by a single vote in both chambers of Congress. The victory was short-lived, with the needs of war and financial stress leading to the chartering of the Second Bank of the United States in 1816, but it too failed to have its 20 -year charter renewed. The United States would proceed to go without a central bank until 1914.

The pivotal point in this second and more serious unraveling of the Federalist plan in 1832 occurred when the same sentiments expressed by the opposition in 1810 truly took root following President Jackson's election in 1828. Though ending in the nation's second largest cyclical downturn, the Jackson presidency left a legacy that saw many more banks created by 1860 and with them an increased density of banking services that would not have occurred as 
rapidly under the earlier regime. Note issue fell into the hands of individual banks with often inadequate regulation at the state level, and though the unit of account remained intact, it was manifested in literally hundreds of different currencies in circulation. The surviving monetary union, if one could call it that, was dealt another blow during the political unrest of the Civil War with the uncoupling of paper money from its backing. Following resumption of the previous system of convertibility at full face value in 1879 , the system was undermined again and again by financial crises through the start of the First World War.

Today’s U.S. monetary union would look quite different had the Federalist plan gone off without a hitch. In this paper I lay out the broad history of how political and economic forces interacted in the United States up to the founding of the Federal Reserve, emphasizing how a basic political union was insufficient for monetary stability, and how the two evolved side by side. In this respect, optimism about the European Union's ability to emerge in the end as a true political and economic union does not seem misplaced.

\section{The Colonial Period}

The thirteen colonies, as individual possessions of the British Empire, comprised a union only in the sense that their geographic proximity allowed people and goods to move across them, and to the extent that the mother country addressed concerns about their governance with some degree of consistency. Political control of each colony resided in the hands of a governor appointed by the crown, and there was no single legislature to represent the colonies as a unit until the Second Continental Congress began to act as a provisional government for the fledgling United States in 1775.

Located on the Empire's periphery, the colonies were not well integrated politically with England, and were largely viewed by Parliament as a store of natural resources meant for 
extraction. Spanish and other coins circulated in the colonies, but their scarcity seemed to serve as a vehicle for financial repression by the crown rather than a problem for the Empire to solve. The metallic nature of the monetary base led to problems of divisibility for small transactions (Sargent and Velde 2003). Disagreements between colonial legislatures, their governors, and the crown about managing these shortages eventually led to makeshift currency systems consisting of foreign coins and paper monies known as "bills of credit." These systems enlarged the stock of money but were inadequate for the volume of desired transactions. Classical monetary theory would predict domestic prices to fluctuate proportionately with the supply of money, yet the ability of an expanded stock of paper money to replace transactions formerly accomplished with barter or bookkeeping allowed the real stock of money to rise in many of the colonies (Rousseau 2007; Rousseau and Stroup 2011).

The main problem with these independent systems was an inability of the colonies to act collectively to control the total supply of money, given that the crown would surely have resisted any attempt to form a political or monetary block. This led to inconsistent monetary policies across colonies and often violent fluctuations in exchange rates of the colonial currencies, with each one denominated in its own "pounds," against each other and against the English sterling. This increased transactions costs and reduced monetary efficiency, which were exacerbated when informational and other frictions kept automatic stabilizers from working.

The New England colonies before 1750 offer an interesting and paradoxical example. Each colony in the region issued its own bills of credit that somehow circulated throughout New England at a common value. The system can thus be considered an early de facto currency zone despite the five separate colonial legislatures (Connecticut, Massachusetts, New Hampshire, Rhode Island, and Vermont) controlling their individual money supplies. Indeed, there was no 


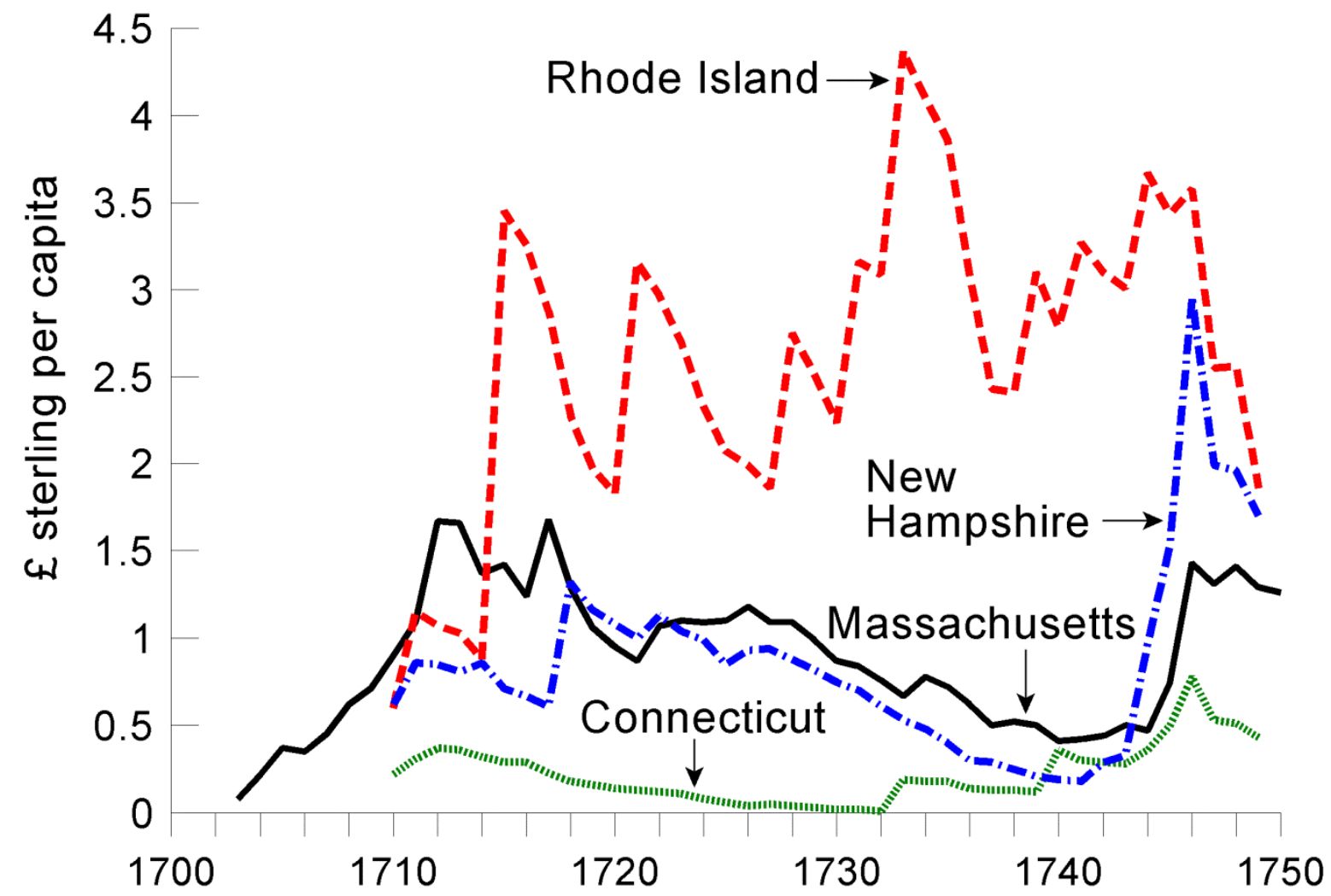

Figure 1 - Bills of credit per capita in the New England colonies, 1703-1749

political union in place among these colonies. Rhode Island, however, discovered early on that it could issue additional bills that would circulate at par with the other New England currencies and at worst de-value the money of the collective as a whole. This was nothing short of an inflation tax that Rhode Island imposed upon its neighbors.

Figure 1 (reproduced from Rousseau 2006, 104), shows the time path of the paper money stock in each New England colony, with all quantities expressed in per capita sterling. ${ }^{1}$ It is clear

\footnotetext{
${ }^{1}$ The quantities of outstanding bills of credit for the New England colonies are from Brock (1992, Table 1). Colonial populations are from U.S. Bureau of the Census (1975, p. 1168, series Z-3, Z-6, Z-7, Z-11) and use constant growth rates to interpolate between decadal benchmarks. Sterling exchange rates are annual averages of local pounds per 100 pounds sterling from McCusker (1978, Table 3.1, pp. 138-45).
} 
that Rhode Island, with one-sixth the population of Massachusetts, had generated a per capita money supply that was three times that of its neighbor. When the other colonies began to sharply increase issues in the $1740 \mathrm{~s}$, rapid inflation commenced which saw prices in Massachusetts rise more than three-fold between 1740 and 1749 (Rousseau and Stroup 2011, 604).

There is no doubt that lack of a central monetary authority in New England allowed a disproportionate share of the seigniorage to accrue to a single small colony, and it is in this sense that the region's natural experiment seems to confirm the view that a successful monetary union is not possible without a viable political one first. But is this too strong an interpretation? After all, the real money stock did rise in New England as a whole by an average annual rate of 14.2 percent $(7.6$ percent in the $1710 \mathrm{~s}, 9.6$ percent in the $1720 \mathrm{~s}, 10.4$ percent in the $1730 \mathrm{~s}$, and 36.2 percent in the 1740s), and Rousseau and Stroup (2011) show that this development was growth promoting. ${ }^{2}$ Even Figure 2, which shows the per capita stock of money in the region deflated by the local price level and in sterling equivalents, indicates that Rhode Island's emissions helped to stabilize money balances in the region as a whole compared to the wide fluctuations shown for the individual colonies in Figure 1.

Is it really that the New England colonies saw some degree of success in their early monetization without a political union in place? Perhaps the apparent strength that these colonies showed in even a loose collective action gave the crown good reason to put an end to fiat paper money with the Currency Act of 1751 and effectively place New England on a specie standard for the remainder of the colonial period.

This begs the question of whether the situation in New England would have been different had it stood as a single political unit rather than a collection of colonies under weak

\footnotetext{
${ }^{2}$ Growth rates are computed by dividing the total money stock in New England by the price level in Massachusetts (see Rousseau and Stroup, 604) and averaging across each decade.
} 


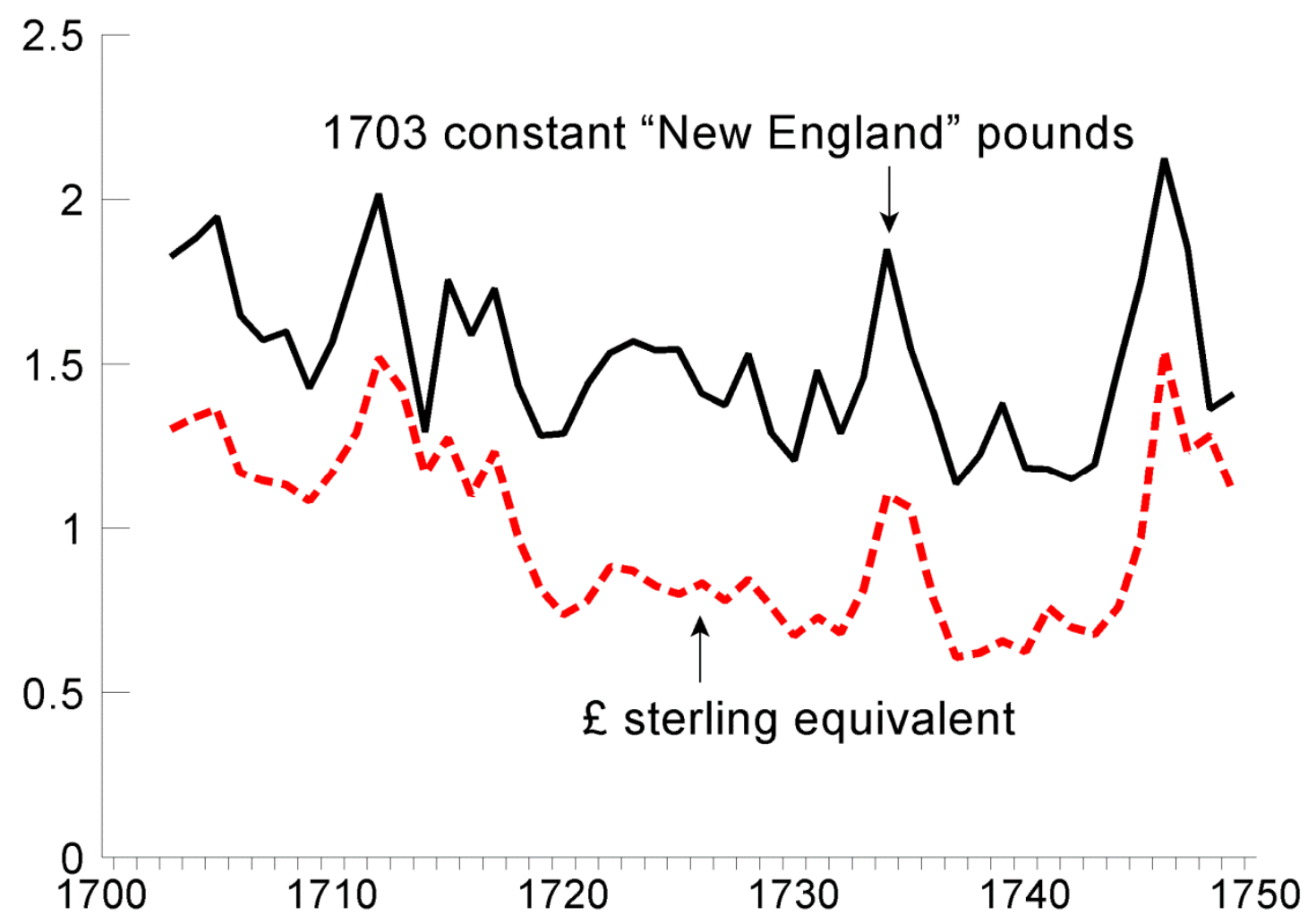

Figure 2 - Per capita money supply in New England, 1703-1749

centralized control an ocean away. Would a political union have led to a better functioning currency zone? Possibly, but one need only turn to the immediate post 1776 period in the nation as a whole for indications that this counterfactual is an unlikely one.

\section{The Revolutionary War and Articles of Confederation}

Upon signing of the Declaration of Independence in 1776, the colonies officially became a self-proclaimed political union, but still lacked components of many successful ones. One deficiency was the lack of a mandate for the national legislature (i.e., the Continental Congress) to tax citizens directly to finance the war of independence that immediately commenced with England. The war brought with it a need for coordinated action among states, and some parts of 
the young United States, and particularly those along its eastern coast, would bear the brunt of the early assaults. The Continental Congress solved the direct taxation problem by issuing paper currency to pay for soldiers and munitions. The $\$ 38$ million "continentals" placed into circulation between 1775 and 1777, which rose to $\$ 200$ million by 1780 (Grubb 2008, 286), entitled the bearer to a stated number of Spanish milled dollars, if one believed what was printed on the face of the bill, but there were no stated provisions for their conversion into coin. This meant that the continentals were backed only by the firmness of beliefs that the bills would be redeemed in hard money if the young nation were to win the war.

Without a clear physical backing, the continentals plunged to near worthlessness by 1781 , with most of the decline complete as early as 1778 . Figure 3 , which shows the nominal and real stock of continentals outstanding between 1776 and 1781, illustrates the course of the decline. ${ }^{3}$ The real stock of continentals kept pace with the nominal through much of 1776, but additional issues were unable to raise the real stock of bills, instead setting it back further. Did the lack of immediate convertibility to specie precipitate the decline? In some respects the answer is yes, as an adequate physical backing could have substituted for a lack of credibility in controlling the supply of notes in the short term. In contrast, consider the dollar of today, which remains relatively stable without a specie backing due to a credible commitment by the U.S. monetary authorities to control its supply. Its success lies in the "backing" implied by the "full faith and credit" of the United States.

Yet it is exceedingly difficult for a weak or young political union to establish the full faith and credit of its own citizens, let alone the international community. The tenuous nature of the

\footnotetext{
${ }^{3}$ The solid line in Figure 3 cumulates the issues of continentals documented in Table 1 of Grubb $(2008,286)$, and the dashed line divides these totals by the paper-to-specie exchange rates reported in Table 2 of Calomiris (1988, 57-58).
} 


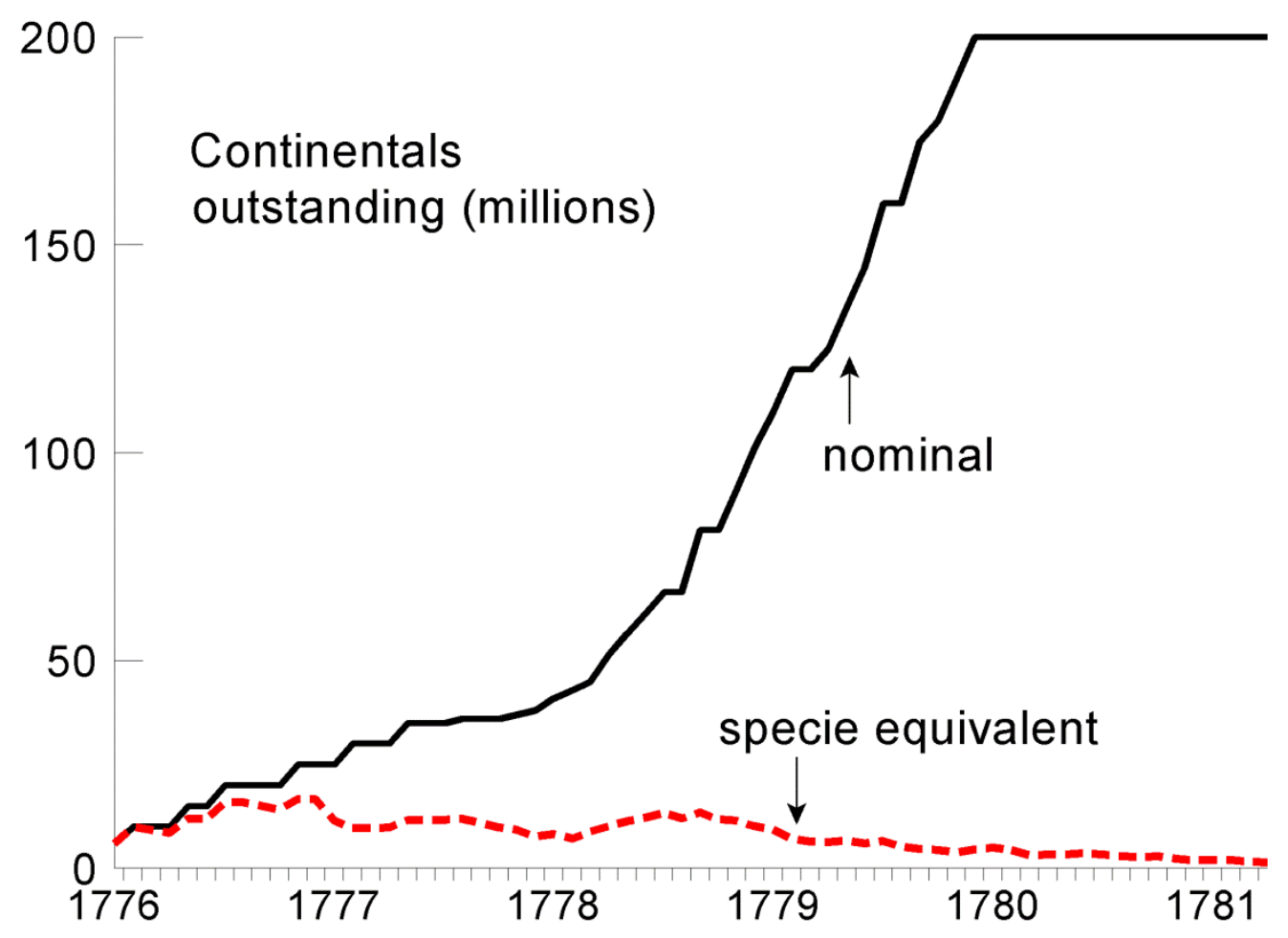

Figure 3 - The rise and fall of the continentals.

political union that was the young United States therefore explains why the currency failed. After all, from the start it was not at all clear that the United States would emerge victorious in the conflict with England. And even if it did, it remained unclear whether the Continental Congress had come to view the continentals as an indirect form of taxation for a federal government that lacked the ability to impose direct taxes. As such a notion took hold, there would be ever-decreasing confidence in the continentals being redeemed (Calomiris 1988). It is perhaps at this point that the real money stock began the free fall that saw it officially de-valued at 40:1 in 1780 and then again at 100:1 in 1790 as part of the Funding Act.

This is not to say that the new political union failed to make a good show of it for a time, with continentals being used to pay soldiers and to pay for munitions in the early stages of the 
Revolutionary war, but in the end the continentals paid for only 40 percent of the conflict

(Calomiris 1988, 58), and it took assistance from domestic as well as French and Dutch investors to ensure that the war could be financed and ultimately won. This makes it safe to say that the nation lacked the confidence of the public in its coordinated efforts for some time into its early history. It is also important to note that the nation had these problems even though its citizens spoke the same language and had similar cultural roots. This suggests that such differences in the European Union may be over-emphasized as reasons why their political union is less than complete.

After the war, the nation continued under a treaty-like document among the states - The Articles of Confederation - in which the states agreed to act collectively, and some states such as Pennsylvania began issuing paper money with some success once again. But depreciation of these new state notes, though never reaching anything near the severity experienced with the continentals, was still unacceptably high. The young nation could in general be characterized as a vulnerable and weak state, with its political union designed primarily for mobilizing defenses in case of foreign attack. This vulnerability was recognized by the Founding Fathers, and created an urgency to overcome opposition that feared central authority in favor of the sea change that was the Federal Constitution.

\section{The Federalist Era}

The early Federalist period is rightfully recognized by a growing group of scholars as the time when the United States made leaps toward achieving the monetary union that persists in some form to this day. Sylla (2002) and Rousseau and Sylla $(2003,2005)$ emphasize a change in the nation's growth trajectory after 1815 that can be plausibly linked to earlier developments championed by the nation's first Secretary of the Treasury, Alexander Hamilton (1789-1795). 
These changes included stronger public finances, support for a variety of banks, some form of a central bank, and active securities markets. The new institutional structure created an environment conducive to entrepreneurship, especially in the major population centers. At the same time, the relative monetary stability that Hamilton established in 1790 came at the price of "re-booting" the nation's failed financial system. This took the form of delivering the final blow to the continentals and a restructuring of U.S. government securities, many of which were held outside of the United States. In other words, whether expected for some time or not, the nation forged a monetary union in the wake of repudiation.

The Federalists' decision to default, however, was the right one. As mentioned above, the continentals had already fallen to near worthlessness by 1778 , were officially de-valued on a generous 40:1 basis in March 1780, and were mostly hoarded by individuals or purchased by speculators in the hopes of eventual redemption at par. Of the nearly $\$ 200$ million in continentals outstanding at the start of 1780 , some $\$ 80-88$ million remained in the hands of the public in 1789 (Grubb 2012, 160). So redemption was likely to benefit speculators rather than soldiers and others who had watched the value of their currency vanish and had long parted with it. Indeed, it would be impossible to identify those who once held these bearer instruments when their value fell. At the same time, the bond holders that had financed the later part of the War also saw the value of their assets fall to pennies on the dollar over the 1780s, and there was speculation in these instruments as well.

Why did Hamilton and the Federalists give priority to holders of state and federal bonds over those holding domestic currency? They did it because the scheme restored some confidence in the United States and its commitment to meet its medium and long-term obligations. Given that the commitment to redeem the continentals at par had always been vague, the young nation 
as a result became better able to attract capital from abroad.

The early financial markets were largely centered in New York, Philadelphia, and Boston. Cowen (2000) and Sylla, Wright, and Cowen (2009) characterize the nation's first securities markets crisis in 1792 as a result of speculative excesses, and emphasizes how the Bank of the United States injected liquidity into the New York money market to calm the selling frenzy. The example demonstrates what the quasi-central bank could potentially do to avert a financial crisis, but hardly represents a systematic response to a nationwide disaster. Rather, it likely kept a small number of wealthy investors in the New York bond market from realizing large losses. The nation's population was still concentrated in the northeast and the restricted reach of the financial sector had not yet come under the pressure that was to rise to a fever pitch some 30 years later.

But there is also little doubt that the monetary union forged by Hamilton and the Federalists brought order to a chaotic system of state currencies through more centralized handling of monetary affairs. And it is also clear that the beginnings of the banking system observed today took shape over the period of the First Bank's charter. The inability of Congressional Federalists to renew that charter in 1811 under President Madison's ambivalent watch proved nearly disastrous as the War of 1812 called for a unified monetary response to England's attempt to regain control of its former colonies. But by the time a new and even more powerful central bank - the Second Bank of the United States - received a federal charter in 1816 and came under the firm control of Nicholas Biddle in 1823, it had become clear that there were limits to the extent to which a monetary union could be built through hubris rather than cooperation among its members.

The available data themselves suggest the weaker long-term aspects of the Federalist 
plan. While Rousseau and Sylla (2005) document a sharp rise in securities available for trading in the major financial centers, it must be noted that those outside of these centers had considerably less access to the capital market. The First Bank did establish eight branches as a result of some legislators seeking to relocate some control over loans and discounts away from the main bank in Philadelphia, yet the Bank and its branches were still often viewed as constricting the supply of money by redeeming notes of other banks whose currency issues seemed considered excessive and thereby lowering total credit. ${ }^{4}$ Some other members of Congress argued vociferously to this effect as the Bank's initial charter was considered. ${ }^{5}$

Hamilton's own statements in 1790 showed a reluctance to embrace a system of branches, but more for the possibility of mismanagement than for their inability to distribute credit widely. ${ }^{6}$ For a country that had just experienced a hyperinflation during the Revolutionary War, caution in this regard would have been prudent at the time, yet it is telling that the aggregate money stock, number of banks, and bank capital took a sharp turn upward only after the nation's first round of Federalism came to a close in 1828 . Figure 4 shows these time paths through $1850 .^{7}$ While the

\footnotetext{
${ }^{4}$ Branches were formed at first in Boston, New York, Baltimore, and Charleston (1792), and later in Norfolk (1800), Washington and Savannah (1802), and New Orleans (1805). In total, the Bank had apportioned 38.5 percent of its $\$ 10$ million in capital to the branches in 1800 and 53.8 percent by 1809 (Wettereau 1937, 278).

${ }^{5}$ Representative Michael Stone of Maryland, for example, stated on February 5, 1790 that "by this bill a few stockholders may institute banks in particular States, to their aggrandizement, and the oppression of others. It will swallow up the State banks" (Wettereau 1942, 71).

${ }^{6}$ Hamilton writes "the argument against it (i.e., branching) is, that each branch must be under a distinct, though subordinate direction, to which considerable latitude of discretion must of necessity be entrusted. And as the property of the whole institution would be liable for the engagements of each part, that and its credit would be at stake, upon the prudence of the directors of every part" (Wettereau 1942, 70).

${ }^{7}$ Estimates for the number of banks and their total paid-in capital are from Rousseau and Sylla (2005), who build these series from data in U.S. Bureau of the Census (1975) and Fenstermaker
} 


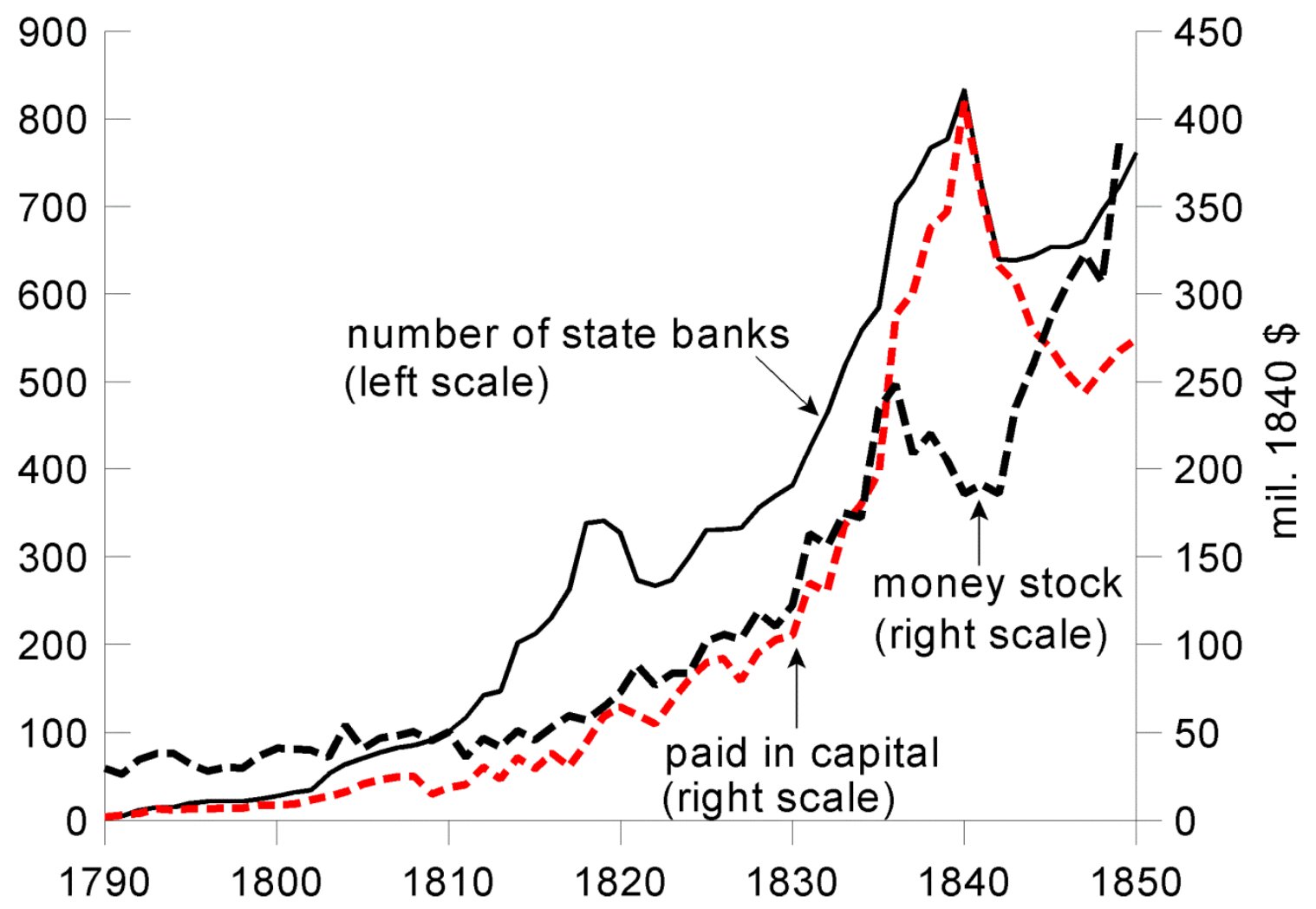

Figure 4 - Monetary and banking aggregates, 1790-1850.

number of state banks did increase rapidly in the 1810 s, their number was low during the time of the First Bank's charter, and slowed again during the 1820s as Biddle took control of its successor. The stock of money and bank capital also developed at a modest pace until rapidly rising with the number of banks in the latter half of the 1820 s.

These expansions of course came to a spectacular conclusion in 1837, but nonetheless raise the question of whether banking could have grown and spread at a pace closer to an optimal one without a quasi-private central bank. In terms of achieving a currency zone with monetary and financial services distributed in proportion to the population, the end of the first Federalist

(1965a, 1965b). The money stock and details about its construction are provided in Rousseau and Sylla $(2005,22-24)$. 
period saw the same political interests that had achieved a common currency and functioning financial system 30 years earlier come under stress from more democratic forces.

\section{Jackson and his Legacy}

Few periods in the U.S. monetary history are more maligned as examples of politics and monetary policy at their worst than the Jackson years (1829-1837). The stage was set upon the Democrats' return to the White House as rhetoric from the President escalated about the dangers of centralized monetary control and misuses of the public funds as allegedly practiced by the Second Bank. ${ }^{8}$ While Jackson's early statements were firm but moderate, politicization of the Bank issue led to the famous "Bank War" and Jackson's 1832 veto of legislation to renew the Bank's federal charter upon its expiration in $1836 .{ }^{9}$ Some consider this event and all that followed in the 1830 s as a serious setback for the U.S. monetary union, but it is possible to view the longer-term consequences in a more positive light.

Indeed, there was a lofty and unassailable goal that Jackson and the Democrats had in mind when they pushed back against Biddle's control of the money creation process. Perhaps it

\footnotetext{
${ }^{8}$ Jackson raised concerns about the constitutionality of the Bank and its privileged position in lending public monies in his 1829 and 1830 annual messages to Congress. At the same time he urged Congress to "in the spirit of improvement and compromise which distinguishes our country and its institutions it becomes us to inquire whether it not be possible to secure the advantages afforded by the present bank through the agency of a Bank of the United States so modified in its principles and structure as to obviate constitutional and other objections" (Second Annual Message, December 6, 1830).

${ }^{9}$ In his Sixth Annual Message to Congress on December 1, 1834, Jackson makes his views on the resuscitation of the Bank clear: "the bold effort the present bank has made to control the Government ... are but premonitions of the fate which awaits the American people should they be deluded into a perpetuation of this institution or the establishment of another like it. It is fervently hoped that thus admonished those who have heretofore favored the establishment of a substitute for the present bank will be induced to abandon it, as it is evidently better to incur any inconvenience that may be reasonably expected than to concentrate the whole moneyed power of the Republic in any form whatsoever or under any restrictions."
} 
was a more equitable distribution of monetary resources among the public that Jackson sought when he removed the government's deposits from the Second Bank in 1833 and 1834, scattering them into a system of depository banks (i.e., "pet" banks) that would become the government's new fiscal agents. The "Specie Circular" of June 1836, which was an executive order requiring all government lands sold to the public to be paid for in specie, was also consistent with this goal. I say this because the Specie Circular, though purportedly issued to slow land sales in areas inundated with an expanded stock of paper money, actually ended up directing coin out of the eastern cities and to points in the West and South (Rousseau 2002, 473-477). The Deposit Act of 1836, sometimes referred to as the "Distribution of the Surplus," also relocated government deposits away from the eastern money centers and to the South (Rousseau 2002, 463-473).

Was Jackson's hope that less centralized control of reserves and money creation would lead to more localized and independent lending decisions that would promote development more effectively in areas outside of the major population centers? This does not seem to have been the immediate result, which may explain some of the negative views that historians typically hold of Jackson's policies. Yet after the downturn of 1837-1843, a more distributed banking system did begin to emerge and gather strength over the next two decades, some of which occurred under a series of "free banking laws" passed by individual states in the 1850 s. These laws set more uniform standards for bank entry and allowed them to start up more quickly.

It is fair to say that the Federalist banking system worked well at a time when the nation's population remained largely concentrated to the east of the Appalachians, but that the system did not fully anticipate the nation's growth potential and by the mid 1840s had become constrictive. Since early in the Federalist era, organizers seeking to start a bank need to obtain a state charter to operate through a special legislative act. This meant that acquiring a state charter was tedious 
and approval depended upon political influence as much as financial resources (Hammond 1957, 574; Bodenhorn 2006). Seeking to advance their political and economic fortunes, legislators protected existing banks and prevented the market from expanding, leading to an intense need for liquidity in developing areas. ${ }^{10}$

Whether the new free banks met this intense need and explicitly contributed to growth in their localities is an open question and recent evidence from Jaremski and Rousseau (2012) suggests that they did not. But immediate impact is not always the appropriate gauge with which to measure success. It is notable that President Tyler had an opportunity to put an end to any Jackson banking legacy in 1843 , but chose not to do so. Perhaps he deserves more credit for broadening the banking system than history has given him. Bodenhorn (2000, 155-156) shows that commercial paper rates were progressing toward convergence across New York, New Orleans, Charleston, and Cincinnati by 1845 . This suggests that if measured by the integration of the short-term capital market and the diffusion of financial services, important steps toward an inclusive monetary union were made without the discipline of a central bank.

Politics were a central ingredient in the evolving monetary union. Bordo (2012) considers the type of central bank that might exist today had Jackson signed the 1832 bill to re-charter the Second Bank, and speculates that it could be a European-style central bank quite different from the Federal Reserve that emerged in 1914. I affirm that this counterfactual could well have occurred had politics not forced Jackson's hand prematurely. To see this, consider the stance of an earlier iconic Democrat, Thomas Jefferson, who opposed chartering the First Bank of the

\footnotetext{
${ }^{10}$ As quoted by Bodenhorn (2003a, 188), A. C. Flagg, a former comptroller of New York State, recalls that merchants, manufacturers, and bankers regularly appealed to politicians for more banks. Delegations were often led by powerful and well-respected individuals such as Albert Gallatin, the nation's longest-serving Secretary of the Treasury (1801-1814).
} 
United States in 1790 and remained a critic of the Bank after his election to the presidency in 1800. Yet even Jefferson over eight years in office came to appreciate the usefulness of the Bank - so much so that he could be considered a supporter by 1808 . His successor, former Federalist turned Democrat James Madison, also held this view. Had the Second Bank's re-charter not been forced onto the legislative agenda by the Whigs four years prior to expiration and turned into a political issue in the 1832 election, Jackson may also have reached a better understanding of the Bank's functions and kept it alive in the course of reaching some compromise with Congress as to what the Bank's lending policy should be and how the government's deposits should be handled. Jackson's early statements on the subject seemed to allow some room for common ground (see footnote 8 above).

In retrospect, though many of Jackson's policies were disruptive, Temin (1969) shows that the inflation and recession of the 1830 s were not entirely due to his missteps. External specie inflows from Mexico and points South expanded the monetary base and the state banks multiplied these reserves at existing ratios, leading to the credit boom and inflation. This ended in a spectacular crash, but two decades of expansion in the banking system followed that took its size to unprecedented heights and led to more equitable distribution of banking activity across the nation's land mass. Certainly the Whigs that succeeded Jackson were unable to alter the new wave in financial and banking structure that followed in his shadow.

\section{The Return of the Whigs and Free Banking}

When William Henry Harrison defeated incumbent Martin Van Buren (Jackson's Vice President and successor) in his 1840 bid for a second term, the White House returned to the Whigs and it was widely anticipated that many of the changes to the banking system brought about by Jackson would be reversed through the re-establishment of a central bank. Harrison's 
untimely death after a month in office did not alter these expectations at first as most assumed that his successor John Tyler would pursue the Whig agenda, but hope was quickly lost as Tyler twice vetoed legislation to establish a new central bank by the early autumn of $1841 .{ }^{11}$ Though the political fallout from this ended in Tyler's expulsion from the Whig party, the nation would nonetheless emerge in 1843 from its 5-year recession in 1843 and render the vetoes of little immediate economic consequence. When the Democrats returned to power in 1844 with the election of James K. Polk, the banking system once again began to expand. And by the early 1850s, under the final Whig Millard Fillmore's watch, a system of "free banks" quickly increased the density of banking services.

It is interesting to consider the potential impact of the Fillmore presidency had Jackson not vetoed the bill for the Second Bank's re-charter in 1832, since the decision about the next charter renewal would likely have fallen into Fillmore's hands. As a Whig, we can only assume that he would have supported such a bill, leaving the United States with some version of Biddle's bank well into the 1870s. In this case it is unlikely that anything like free banking or the National Banking System would ever have emerged.

Free banking involved states passing their own laws that allowed virtually anyone to form a bank so long as it adhered to state requirements regarding capital, reserves, collateral, and note issuance. While free banking was thus far from "laissez-faire," banks could now enter the industry at relatively low cost and with a minimum of legislative barriers. Free banks expanded rapidly in the 1850s, and by 1860 there were 1,371 state banks (including free banks) operating in the United States, more than twice the number in operation in 1845 (Weber 2006, 35).

\footnotetext{
${ }^{11}$ Tyler was a former Democrat and always an advocate for state's rights, so his opposition to chartering a third central bank should not have been an enormous surprise to the Whigs in Congress and in his cabinet who had supported his somewhat controversial accession to the "full" presidency only months before.
} 
Starting with Michigan in 1837 and continuing through 1860 in Pennsylvania, free banking laws replaced legislative processes for starting banks with a defined set of capital, reserve, and note issue requirements that varied from state to state. Most laws permitted entry with low administrative barriers and small sunk costs. Banks and liquidity could then expand with population and demand without political interference. In total, 18 states passed free banking laws, but most were not passed until the early 1850s (Rolnick and Weber 1983, 1082).

Despite establishing liquidity on the frontier, it is not clear that free banks promoted development in their immediate locations, and free banks had a greater propensity to close than charter banks (Jaremski and Rousseau 2012). Such closures would sometimes occur before free banks could have positive effect on their communities. Rolnick and Weber (1983) show that this was not because free banking was an inherently unstable institutional arrangement, but rather a result of fluctuations in the value of collateral bonds required by individual states for securing notes. Because the quality of bonds acceptable for securing notes varied across states, with some even allowing non-government bonds such as railroad securities to secure notes, free banks in states with looser collateral standards were more vulnerable to negative business cycle fluctuations or particular industry-specific shocks.

The expansion of banking during the Jackson and free bank eras distributed banks across the country and furthered integration in the early capital market. This was consistent with promoting a monetary union, but in other respects represented a step backward. The Federalist system did allow for a wide range of notes issued by individual banks under the general control of the First and Second Banks, but the expansion after the Second Bank's demise generated an unprecedented multiplicity of notes. With it came problems with counterfeiting and asymmetric information regarding the condition of banks that issued notes. When a note would circulate far 
from the bank of issue (i.e., the only place required to redeem the note in specie), there were considerable costs involved with returning the note to that particular bank, including the possibility that the bank that had issued the note would be closed by the time the note reached its destination (Gorton 1996). This led to notes of different banks trading at discounts against each other and based upon the location of a particular note holder.

The non-uniformity of the currency led to regular publications in the major cities - called "bank note reporters" - that listed various known bank notes along with their value with respect to specie. This was not as straightforward as it may seem when considering discounts for notes issued at great distances or from remote locations. One problem with reporters was that there were considerable lags in updating information about particular notes so that it would never be clear how much a note would be worth upon its return to the issuing bank. This would not affect the ability of distant notes to trade at their reported values in the major cities so long as there were no systematic biases in the discounting errors, but the uncertainty generated discounts that could be quite deep.

One way to think of conditions by the late 1850 s was that Hamilton's unit of account had indeed prevailed, but that a uniform currency circulating at values consistent with that unit of account had not. This caused confusion and inefficiency in the monetary system. When free banks began to close in large numbers in Indiana, Minnesota, Wisconsin and other states, the problems with the system and the lack of a common currency backed by a nationwide and uniform set of acceptable collateral reached the fore, but the Civil War intervened to delay a resolution (Jaremski 2010).

These facts suggest that the National Banking Acts of 1863 and 1864 sought to retain the enabling aspects of free banks but with improvements in capital adequacy and in the quality and 
uniformity of collateral required for note issue. By eliminating note discounts across locations, these changes represented further progress towards monetary union. Sylla (1969) and James (1978) note that the restrictiveness of some of these regulations had negative effects on the availability of credit later in the 19th century, but it was the legacy of free banking that allowed conditions under the National Banking System to develop to the point where the rules could bind. In other words, the establishment of free banks in areas that had previously gone without banks generated conditions where National Banks could start up knowing that there was a demand for their services. Though the original free banks themselves may not have had much of an immediate and direct impact on growth, they left a footprint of banking in rural areas that would eventually be filled by national banks and later by a second wave of state banks that brought the age of deposits with them.

\section{The Civil War and National Banking System}

The free bank and the National Banking eras were punctuated by the largest political upheaval in U.S. history, which led to the succession of eleven Southern states in 1861 and the nation's bloodiest war. The Union lacked the resources needed to prosecute the war, and could not float bonds among domestic and foreign investors at interest rates that were sufficiently low. It was in the midst of these difficulties that the Union began to issue paper money - the greenbacks - through the Legal Tender Acts of 1862 and 1863 . The $\$ 450$ million greenbacks issued by 1864 were not payable on demand in specie and quickly began trading at discounts from gold, with the exchange ratio peaking at about 2:1 in 1865 (Kindahl 1961, 36).

One might consider this as a continental-like experience all over again, but the Federal government was able to maintain confidence in its ability to redeem the greenbacks at a rate reasonably close to par. In late 1865 the Treasury announced a policy of retiring greenbacks and 
the Congress passed a resolution approving this policy, yet progress slowed within a few years with only 10 percent of the greenbacks retired by 1868 (Kindahl 1961, 45). The Public Credit Act of 1869 turned the informal commitment to retire the greenbacks into law, but it took the Resumption Act of 1875 for a firm schedule of par convertibility to get established. In the end, resumption went off smoothly in 1879 not because the government retired the greenbacks but rather because it allowed the nation to grow into the new money supply. Some bolstering of specie reserves in 1878 and 1879 headed off any remaining doubt about a return to convertibility.

In the meantime, the National Banking Acts improved the safety of the financial system by imposing minimum capital requirements for those starting National banks, and by clawing back outstanding notes issued by state banks through a prohibitive 10 percent tax on them. ${ }^{12}$ Note issues were also controlled more rigorously under the new Office of the Comptroller of the Currency, which replaced state-determined collateral requirements with national ones that called for the deposit of Federal bonds in return for privilege of issuing notes. The stringent collateral requirements, however, coupled with the tax on state bank notes and the minimum capital rules caused many state banks to end their operations and in general kept the number and diffusion of national banks at less than optimal levels. A nationwide ceiling of $\$ 300$ million on the total outstanding national bank notes also began to bind until it was lifted in 1875 .

The greenbacks were not uninvolved in these developments, as the slower growth in the money supply associated with the new regulations facilitated the deflation required to achieve resumption. By then the nation had finally achieved a uniform currency, with both bank notes and government notes trading at par with gold. The bank notes even looked the same, as the

\footnotetext{
${ }^{12}$ The original legislation required national banks in communities with less than 3,000 persons to have at least $\$ 50,000$ in capital. National banks were also to hold at least one-third and no less than $\$ 30,000$ of their paid-in capital in federal bonds. The 10 percent tax on state bank notes took effect on October 1, 1866.
} 
Comptroller would receive federal bonds as collateral from national banks and send back notes that were identical across banks other than carrying the name of each particular bank. The Comptroller could in turn liquidate the collateral bonds and pay off depositors in full in the event that a national bank was forced to close.

Banks found that the high collateral and capital requirements made issuing notes often less profitable than expected and responded by focusing on deposits instead. As the demand for deposits and the services associated with them increased over the latter part of the $19^{\text {th }}$ century, state banks had a resurgence in the 1880s and 1890s, which corrected some of the deficiencies in the diffusion of banking. State capital requirements were usually lower than those required for national banks, so state banks found that deposits gave them an innovative way to fund earning assets, making note issue unnecessary for having a successful bank. With the passage of the Gold Standard Act in 1900, minimum capital requirements in low population areas were lowered to $\$ 25,000$ for starting a national bank, and the number of banks saw another surge.

Even though the capital market was becoming increasingly integrated by 1900 as evidenced by narrowing differentials in regional interest rates (Davis 1965), the banking system in the National period was vulnerable to liquidity squeezes. Sprague (1910) describes the major disturbances that occurred in 1873, 1893, and 1907, along with less severe ones in 1884 and 1890. Given that the nation lacked a lender of last resort, which was a direct consequence of going without a central bank for so long, it fell upon private associations of bankers to operate clearinghouses that could pool resources and keep markets liquid in times of strain. These systems more or less worked in the earlier crises but the system exhibited excessive strain in 1907. Even with a uniform currency, there were inadequate mechanisms for handling systemic risks and so the nation remained still somewhat removed from full monetary integration. 


\section{Conclusion}

The founding of the Federal Reserve in 1914 and all that came with it was a watershed event in the establishment of the U.S. monetary union. Though the U.S. political union had been fractured only 50 years earlier, the Federal Reserve arose in a period of relative political stability - a situation that for the most part continues to the present. The Federal Reserve was formed as a quasi-public bank with power distributed among twelve regional branches, and this regional emphasis seems to reflect the Jacksonian concern about excessive centralization. In some ways, however, the Federal Reserve can also be considered a variant of how the First Bank of the United States ended up. Even though Hamilton initially opposed branching, his bank did create them. So did the Federal Reserve, but it also allowed for an adequate system of affiliated banks and avoided the problem of these banks issuing their own non-uniform currencies. In other words, the structure of the Federal Reserve can be seen as a compromise of Federalist and Democratic leanings - one that tried to take advantage of the best features of each.

The Federal Reserve was formed with adequate powers for handling systemic crises, and so its unwillingness to use these levers during the Great Depression is not so much a fault of the system's design as it was a misunderstanding of how the tools at hand could be deployed in times of crisis. The locus of power shifted to the Board of Governors after the Depression and away from the regional banks, returning somewhat to a regime where control of the money supply and monetary affairs was more centralized, but the result still had a wide range of member banks and did not concentrate decision making to the extent that the Federalists imagined. Complaints by the public about the Federal Reserve today often involved perceived policy shifts toward more centralized control, but indeed banking and financial services are distributed and the central bank is ready and able to act strongly to head off systemic risks. 
These advantages did not come quickly to the young United States, and if they were in any sense a result of the political union formed in 1789 , they did not follow directly from it. The political and monetary equilibrium settled upon in 1790 was a temporary one that has been subjected to shock upon shock along both dimensions for more than two centuries. This is not to say that ratification of the Constitution was less than a defining moment for the nation, nor that

Hamilton's financial system was less than a leap forward, but to suggest that the establishment of the political union ensured the course of future events is clearly an overstatement. The U.S.

financial system that we observe today was not the result of a "big bang," but rather derives from a fluid, ever-evolving, and organic process of improvement, misstep and improvement driven by interactions between political and monetary forces. It seems likely to this observer that similar forces will interact gradually to bring about monetary and political union in Europe as well, but that unlike the historical case of the United States, it will require less than a century to achieve.

\section{References}

Bodenhorn, Howard. 2000. A History of Banking in Antebellum America: Financial Markets and Economic Development in an Era of Nation-Building. New York: Cambridge University Press.

Bordo, Michael D. 2012. Could the United States have had a better central bank? An historical counterfactual speculation. Journal of Macroeconomics 34:3, 597-607.

Brock, Leslie V. 1992. The colonial currency, prices, and exchange rates. Essays in History 34, http://etext.virginia.edu/journals/EH/EH34/brock34.htm.

Calomiris, Charles W. 1988. Institutional failure, monetary scarcity, and the depreciation of the continental. Journal of Economic History 48, 47-68.

Cowen, David J. 2000. The First Bank of the United States and the securities market crash of 1792. Journal of Economic History 60:4, 1041-1060.

Fenstermaker, J. Van. 1965a. The Development of American Commercial Banking: 1782-1837. Kent, OH: Kent State University Press. 
Fenstermaker, J. Van. 1965b. The statistics of American commercial banking, 1782-1818. Journal of Economic History 25, 400-414.

Gorton, Gary. 1996. Reputation formation in early bank note markets. Journal of Political Economy 104, 346-397.

Grubb, Farley. 2008. The continental dollar: how much was really issued? Journal of Economic History 68:1, 283-291.

Grubb, Farley. 2012. State redemption of the continental dollar, 1779-90. The William and Mary Quarterly 69:1, 147-180.

Hammond, Bray. 1957. Banks and Politics in America: From the Revolution to the Civil War. Princeton, NJ: Princeton University Press.

James, John. 1978. Money and Capital Markets in Postbellum America. Princeton, NJ: Princeton University Press.

Jaremski, Matthew. 2010. Free bank failures: Risky bonds versus undiversified portfolios. Journal of Money, Credit and Banking 43:8, 1565-1587.

Jaremski, Matthew, and Peter L. Rousseau. 2012. Banks, free banks, and U.S. economic growth. Economic Inquiry, forthcoming.

Kindahl, James K. 1961. Economic factors in specie resumption in the United States 1865-79. Journal of Political Economy 69:1, 30-48.

McCusker, John J. 1978. Money and Exchange in Europe and America, 1600-1775: A Handbook. Chapel Hill, NC: University of North Carolina Press.

Rolnick, Arthur J., and Warren E. Weber. 1983. New evidence on the free banking era. American Economic Review 73:5, 1080-1091.

Rousseau, Peter L. 2002. Jacksonian monetary policy, specie flows, and the panic of 1837. Journal of Economic History 62:2, 467-488.

Rousseau, Peter L. 2006. A common currency: early US monetary policy and the transition to the dollar. Financial History Review 13, 97-122.

Rousseau, Peter L. 2007. Backing, the quantity theory, and the transition to the U.S. dollar. American Economic Review 97, Papers and Proceedings, 266-270.

Rousseau, Peter L., and Richard Sylla. 2003. Financial systems, economic growth, and globalization. In Bordo, M., A. Taylor, and J. Williamson, eds., Globalization in Historical Perspective. Chicago: University of Chicago Press, 373-413. 
Rousseau, Peter L., and Richard Sylla. 2005. Emerging financial markets and early U.S. growth. Explorations in Economic History 42, 1-26.

Sargent, Thomas J. 2012. Nobel lecture: United States then, Europe now. Journal of Political Economy 120 (1), February, 1-40.

Sargent, Thomas J., and François R. Velde. 2003. The Big Problem of Small Change. Princeton, NJ: Princeton University Press.

Sprague, O. M. W. 1910. History of Crises under the National Banking System. Washington, DC: Government Printing Office.

Sylla, Richard. 1969. Federal policy, banking market structure, and capital mobilization in the United States, 1863-1913. Journal of Economic History 29: 657-686.

Sylla, Richard. 2002. Financial systems and economic modernization. Journal of Economic History 62, 277-292.

Sylla, Richard, Robert E. Wright, and David J. Cowen. 2009. Alexander Hamilton, central banker: crisis management during the U.S. financial panic of 1792. Business History Review 83, 61-86.

Temin, Peter. 1969. The Jacksonian Economy. New York: W. W. Norton and Company.

U.S. Bureau of the Census. 1975. Historical Statistics of the United States: from Colonial Times to 1970. Washington, DC: Government Printing Office.

Weber, Warren E. 2006. Early state banks in the United States: how many were there and where did they exist? Federal Reserve Bank of Minneapolis Quarterly Review 30:2, 28-40.

Wettereau, James O. 1937. New light on the First Bank of the United States. The Pennsylvanian Magazine of History and Biography 61, 263-285.

Wettereau, James O. 1942. The branches of the First Bank of the United States. Journal of Economic History 2, 66-100. 